\title{
AKTIVITAS ANTIMIKROBA EKSTRAK RIMPANG JERINGAU (Acorus calamus) TERHADAP PERTUMBUHAN Candida albicans
}

\author{
Nurlaili Susanti \\ Fakultas Sains dan Teknologi \\ UIN Maulana Malik Ibrahim Malang
}

Diterima : 15 Juni 2016 Ditinjau : 18 Oktober 2016 Disetujui : 07 November 2016

\begin{abstract}
Abstrak. Infertilitas adalah ketidakmampuan seorang wanita berusia lebih dari 35 tahun untuk hamil setelah mencoba kurang lebih selama 6 bulan, dengan hubungan seksual yang normal dan tanpa menggunakan kontrasepsi. WHO memperkirakan bahwa 8-12\% dari pasangan di seluruh dunia memiliki masalah dalam kehamilan. Baru-baru ini, manajemen infertilitas dengan cara operasi, obat-obatan, dibantu teknologi reproduksi (fertilisasi in-vitro / IVF) selain mahal, tidak selalu berhasil. Saat ini, banyak orang menggunakan herbal dalam pengobatan berbagai penyakit. Madura dikenal sebagai salah satu etnis yang memiliki pengetahuan tentang obat tradisional atau "herbal" terutama yang berkaitan dengan keharmonisan perkawinan. Rimpang Jeringau (Acorus Calamus) adalah salah satu bahan baku "Jamu Subur Kandungan" yang mengatasi masalah infertilitas perempuan. Penelitian ini menguji aktivitas antimikroba Jeringau Rimpang (Acorus Calamus) untuk menghambat pertumbuhan Candida albicans. Hasil penelitian ini diharapkan menjadi dasar untuk standardisasi dan saintification dari "Jamu Subur Kandungan". Uji aktivitas antimikroba dari ekstrak Jeringau Rimpang (Acorus Calamus) menunjukkan penghambatan pertumbuhan Candida albicans dengan Konsentrasi Hambat Minimum (KHM) sebesar 0,5\%.
\end{abstract}

Abstrak : Acorus calamus, Antimicrobial activity, Candida albicans

\begin{abstract}
Infertility is the inability of a woman over 35 years to pregnant after trying for at least 6 months, with normal sexual intercourse and without use birth control. WHO estimates that 8-12\% of couples worldwide have problems in pregnancy. Recently, management of infertility with surgery, medicine, assisted reproductive technology (in-vitro fertilization/IVF) in addition to expensive, not always successfully. Currently, many people use herbs in the treatment of various diseases. Madura is known as one of the ethnic that have knowledge of traditional medicine or "herbal" especially related to marital harmony. Rhizome of Jeringau (Acorus Calamus) is one of the raw materials of "Jamu Subur Kandungan" which overcome the problem of female infertility. This study examined the antimicrobial activity of Jeringau Rhizomes (Acorus Calamus) to inhibit the growth of Candida albicans. The results of this study are expected to be the basic for standardization and saintification of "Jamu Subur Kandungan". Antimicrobial activity test of Jeringau Rhizome Extract (Acorus Calamus) showed inhibition of Candida albicans growth with Minimum Inhibitory Concentration (MIC) at 0.5\%.
\end{abstract}

Key words : Acorus calamus, Antimicrobial activity, Candida albicans

\section{PENDAHULUAN}

Indonesia merupakan salah satu negara yang kaya akan keanekaragaman hayati. Sebanyak 940 jenis tumbuhan telah terdaftar sebagai penyedia bahan ramuan untuk keperluan pengobatan secara tradisional (Rifa'i, 2000). Menurut Zuhud (2003), kurang lebih 400 kelompok etnis masyarakat Indonesia memiliki hubungan yang erat dengan tumbuhan obat, diantaranya kelompok etnis Madura. Madura dikenal sebagai salah satu etnik yang memiliki kekayaan pengetahuan tradisional dalam bidang obat tradisional atau "jamu" khususnya yang berkaitan dengan keharmonisan suami istri (Handayani dan Sukirno, 2000). Kekayaan etnik Madura dalam bidang pengobatan tidak hanya terbatas dalam upaya menjaga kesehatan reproduksi. Pengetahuan penting 
lainnya dalam pengobatan tradisional meliputi pengetahuan tentang klasifikasi penyakit dan sifat tanaman obat, cara-cara pengobatan, cara perawatan tubuh, jenis-jenis tanaman obat, bahkan jamu untuk sapi (Purwanti, 2001).

Salah satu jamu Madura yang banyak digunakan adalah Jamu Subur Kandungan. Jamu ini berkhasiat mengatasi masalah infertilitas wanita. Rimpang jeringau (Acorus calamus) merupakan salah satu bahan baku Jamu Subur Kandungan. Tanaman terna ini berbentuk mirip rumput, batangnya tinggi, daun dan rimpangnya memiliki aroma yang kuat. Rimpang Jeringau tumbuh liar sepanjang tahun di pinggir sungai, hutan, rawa-rawa maupun lahan yang tergenang air. Tanaman herbal ini secara empiris telah digunakan oleh masyarakat dalam mengobati berbagai macam penyakit diantaranya diare, disentri, dan cacingan (Gholkar, 2012 ; Atsiri Indonesia, 2006).

Rhizoma Rimpang Jeringau memiliki kandungan zat aktif $\beta$-asarone, $\alpha$-asarone, Sequesterpenes, $\beta$-daucosterol, triterpenoid, dan polisakarida larut air (Nandakumar, 2013). Penelitian Sihite (2009) menunjukkan adanya kandungan minyak atsiri pada rimpang jeringau, yang diketahui memiliki aktivitas antimikroba terhadap Pseudomonas aeruginosa, Candida albicans, dan Penicillium marneffei. Penelitian ini menguji aktivitas antimikroba Rimpang Jeringau (Acorus calamus) dalam menghambat pertumbuhan Candida albicans. Hasil penelitian ini diharapkan dapat menjadi dasar dalam standarisasi dan saintifikasi "Jamu Subur Kandungan".

\section{METODE PENELITIAN}

\section{Ekstraksi Rimpang Jeringau (Acorus calamus)}

Prosedur pertama yang dilakukan adalah membuat ekstrak Rimpang Jeringau (Acorus calamus). Rimpang jeringau yang digunakan dalam penelitian ini didapat dari Herba Medika Malang. Sampel tanaman dicuci bersih dan dikeringanginkan. Selanjutnya sampel dipotong kecil-kecil dengan gunting dan dikeringkan dengan oven pada suhu $30-37{ }^{\circ} \mathrm{C}$ selama 1-2 jam. Kemudian sampel kering dihaluskan dengan blender sampai menjadi serbuk dan diayak dengan ayakan 60 mesh.

Serbuk yang diperoleh dilakukan ekstraksi dengan metode maserasi menggunakan pelarut etanol $70 \%$. Sebanyak $60 \mathrm{~g}$ serbuk direndam dalam $300 \mathrm{~mL}$ pelarut etanol selama 24 jam, kemudian dishaker selama 3 jam. Rendaman disaring dan ampas yang diperoleh dimaserasi kembali dengan pelarut yang sama. Proses ini dilakukan sebanyak 3 kali pengulangan sampai filtratnya berwarna bening. Selanjutnya disaring dan ampasnya dikeringkan pada suhu ruang hingga terbebas dari pelarut etanol. Ekstrak yang diperoleh dipekatkan dengan rotary evaporator.

\section{Uji Aktivitas Antimikroba Ekstrak Rimpang Jeringau terhadap Candida albicans}

Candida albicans yang digunakan dalam penelitian ini adalah isolat 41-SV yang diperoleh dari Laboratorium Mikrobiologi Fakultas Kedokteran Universitas Brawijaya Malang. Identifikasi ulang dilakukan sebelum dan setelah dipakai sebagai materi penelitian. Identifikasi dilakukan dengan menanam koloni jamur pada media Saboroud Dextrose Agar (SDA), pewarnaan gram dan germinating tube test. Standar kepadatan jamur yang digunakan adalah $10^{6} \mathrm{CFU} / \mathrm{ml}$.

Uji aktivitas antimikroba ekstrak Rimpang Jeringau dilakukan dengan metode Tube Dilution Test. Ekstrak Rimpang Jeringau yang diperoleh dibuat suspensi dengan media Saboroud Dextrose Broth (SDB) dalam tabung reaksi dengan konsentrasi $4 \%$ (kontrol bahan), $2 \%, 1 \%, 0,5 \%$, dan $0 \%$ (kontrol jamur). Konsentrasi tersebut dibuat dengan memakai rumus pengenceran secara serial. Ke dalam masing-masing tabung dimasukkan $10 \mu \mathrm{l}$ larutan Candida albicans yang telah diencerkan dalam Phosphate Buffer Saline (PBS). Kemudian diinkubasi pada suhu $37^{\circ} \mathrm{C}$ selama 48 jam dan diamati perubahan kekeruhannya. Pada tabung dengan konsentrasi tertentu dimana dijumpai kekeruhan yang mulai menghilang ditentukan sebagai Kadar Hambat Minimal (KHM) yaitu kadar minimal ekstrak yang mampu menghambat pertumbuhan jamur Candida albicans. 


\section{HASIL PENELITIAN}

Penanaman jamur Candida albicans pada media Saboroud Dextrose Agar (SDA) didapatkan gambaran koloni yang merupakan ciri khas Candida albicans, yaitu koloni berwarna putih kekuningan, pekat, berdiameter antara 1-2 $\mathrm{mm}$, dan beraroma ragi (gambar 1a). Dengan pewarnaan Gram tampak sel dengan sifat Gram positif, berbentuk oval, dan terdapat budding (gambar 1b).

a

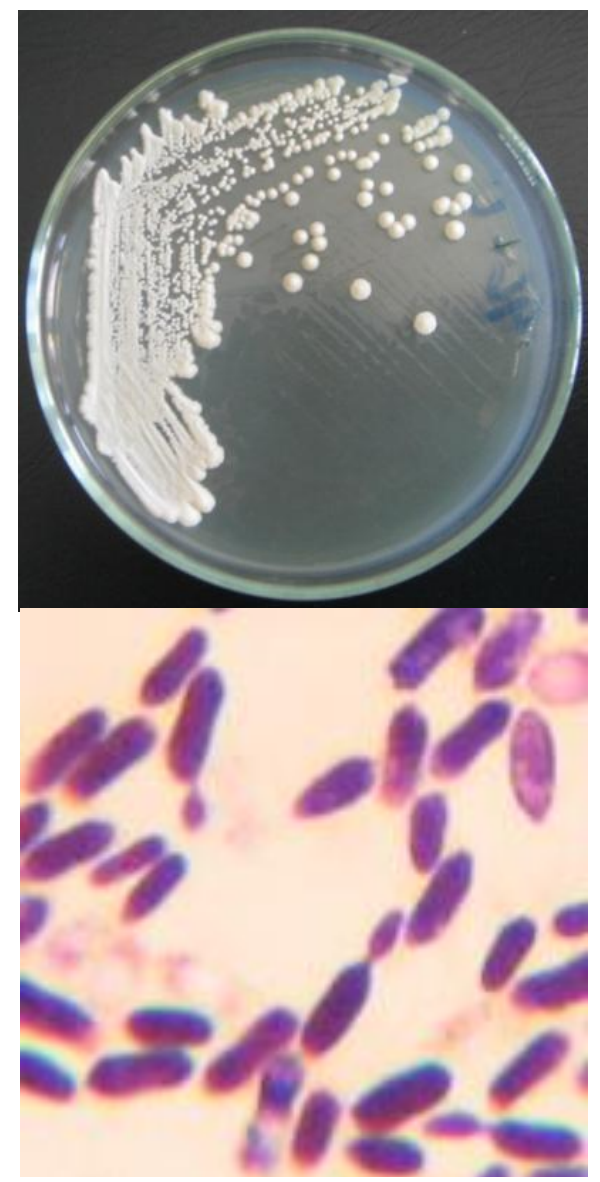

Gambar 1. Candida albicans (a) Koloni Candida albicans (b) Bentukan budding

Hasil pengujian aktivitas ekstrak etanol Rimpang Jeringau (Acorus calamus) dengan metode Tube Dilution Test menunjukkan kemampuannya dalam menghambat pertumbuhan jamur Candida albicans. Dari kelima konsentrasi yaitu 4\% (kontrol bahan), $2 \%, 1 \%, 0,5 \%$, dan $0 \%$ (kontrol jamur), dapat diamati bahwa kekeruhan mulai menghilang pada konsentrasi 0,5\%. Oleh karena itu, Kadar Hambat Minimal (KHM) ekstrak Rimpang Jeringau (Acorus calamus) dapat ditentukan yaitu pada konsentrasi $0,5 \%$.

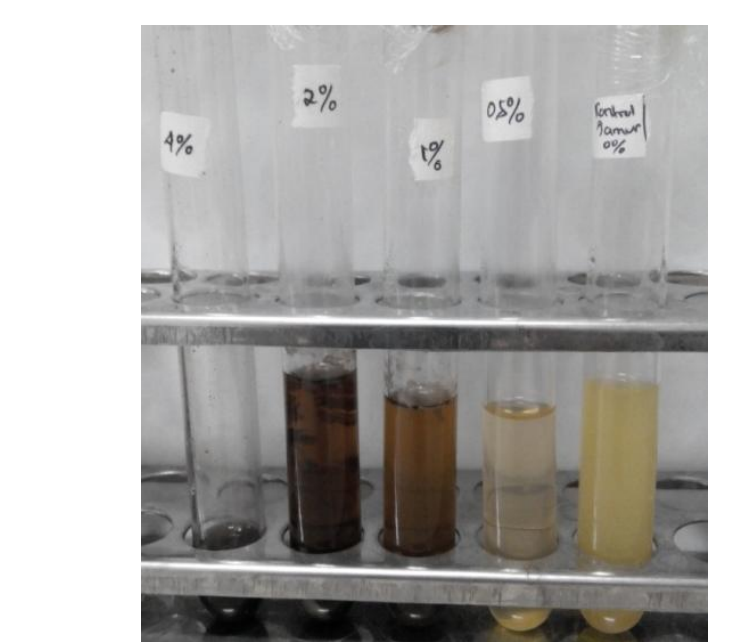

Gambar 2. Hasil Uji Aktivitas Ekstrak Rimpang Jeringau (Acorus calamus) terhadap Candida albicans

\section{PEMBAHASAN}

Pengujian ekstrak etanol Rimpang Jeringau (Acorus calamus) menunjukkan adanya aktivitas penghambatan terhadap pertumbuhan jamur Candida albicans. Aktivitas penghambatan ini dapat dilihat dari hilangnya kekeruhan pada tabung reaksi mulai konsentrasi ekstrak 0,5\%. Adanya aktivitas antimikroba ekstrak Rimpang Jeringau (Acorus calamus) diduga karena kandungan senyawa metabolit sekunder yang berperan sebagai antimikroba. Berdasarkan penelitian sebelumnya, Rimpang Jeringau (Acorus calamus) memiliki kandungan fitokimia diantaranya steroid, fenol, tannin, flavonoid, glikosida, diterpen, triterpen dan alkaloid (Barua, et al, 2014).

Flavonoid merupakan senyawa fenol yang bekerja dengan cara mendenaturasi protein yang dapat menyebabkan aktifitas metabolisme sel jamur berhenti, karena semua aktifitas metabolisme sel dikatalisis oleh suatu enzim yang merupakan protein. Aktivitas antimikroba dari flavonoid terjadi karena kemampuannya untuk berikatan dengan adhesin, polipeptida dinding sel dan membrane-bound enzymes, karena flavonoid memiliki kemampuan untuk membentuk kompleks dengan protein ekstraseluler terlarut dan dengan dinding sel, sehingga mikroorganisme tidak dapat melekat dan menginvasi sel (Harborne, 1996).

Tanin dan alkaloid terdapat pada kadar yang lebih rendah dalam ekstrak Rimpang Jeringau (Acorus calamus) (Barua, et al, 
2014). Tanin merupakan senyawa metabolit sekunder pada tumbuhan yang bersifat sebagai antimikroba dengan membentuk ikatan yang stabil dengan protein sehingga terjadi koagulasi protoplasma mikroba. Daya antimikroba tannin sangat toksik terhadap filamentous fungi dan bakteri (Harborne, 1996). Alkaloid memiliki kemampuan sebagai antimikroba, dengan cara mengganggu komponen penyusun peptidoglikan pada sel mikroba, sehingga lapisan dinding sel mikroba tidak terbentuk secara utuh dan menyebabkan kematian sel (Robinson, 1995).

Dari hasil penelitian dapat disimpulkan bahwa Ekstrak Rimpang Jeringau (Acorus calamus) secara in vitro memiliki daya antifungal terhadap pertumbuhan Candida albicans. Perlunya penelitian lebih lanjut mengenai kandungan bahan-bahan aktif yang terdapat dalam ekstrak Rimpang Jeringau (Acorus calamus) maupun penggunaan metode lain seperti spektrofotometri.

\section{DAFTAR PUSTAKA}

Atsiri Indonesia. 2006. Atsiri. Online. http://atsiriindonesia.com//tanaman.php /id\&//detail_news 1/desknews=deskripsiba littro. diakses 21 Agustus 2014

Dalimarta, S. 1998. Atlas Tumbuhan Obat Indonesia Jilid I. Jakarta : Trubus Agriwidya Press.

Gholkar MS, Mulik MB, Laddha KS. 2012. Fate of $\beta$-asarone in Ayurvedic Sodhana process of Vacha. J Ayurveda Integr Med.Reid, T. Traditional Chinese Herbal Medicine, 28 (1).

Handayani, L dan S. Sukirno. 2000. Pemanfaatan Jamu Rapat dan Keputihan serta Tradisi yang Menyertai Pada Masyarakat Madura. Dalam: Purwanto dan Walujo, E.B. (eds). Prosiding Seminar Lokakarya Nasional Etnobotani III Denpasar Bali.

Harborne, JB, 1996. Metode fitokimia; Penuntun Cara Modern Menganalisis Tumbuhan Edisi ke-2. Bandung : ITB Press.

Nandakumar S, Menon S, Shailajan S. 2013. A rapid HPLC-ESI-MS/MS method for determination of $\beta$-asarone, a potential anti-epileptic agent, in plasma after oral administration of Acorus calamus extract to rats. Biomed Chromatogr, 15 (1).

Purwanti, U. 2001. Pengembangan Tumbuhan Obat Berbasis Masyarakat di Pulau Madura. Program Warta KEHATI Edisi Januari.

Rifa'i, M.A. 2000. Pingit, Pijet dan Pepahit: Peran Tumbuhan dalam Kosmetik Tradisional Indonesia seperti Dicerminkan di Daerah Madura. Online. http://dbp.gov.my/mab2000/Penerbitan/Ra mpak/rspijet21.pdf. diakses 22 Agustus 2014.

Robinson, T. 1995. Kandungan organik tumbuhan tinggi Edisi Kedua, Penerjemah; Kokasih Padmawinata. Bandung : ITB Press.

Sihite, DF, 2009. Karakteristik minyak atsiri jeringau (Acorus calamus). Skripsi Fakultas Pertanian Universitas Sumatra Utara. USU Repository, Sumatra.

Zuhud, A. 2003. Pengembangan Tumbuhan Obat Berbasis Konsep Bioregional (contoh kasus di kawasan meru betiri jawa timur). Makalah Filsafat Sains Program Pascasarjana. Bogor : IPB Press. 